\title{
Characteristic of Protein Hydrolyzate of Snakehead Fish (Channa striata) Head by Using the Treatment of Different Bromelin Enzyme Concentration and Hydrolysis Time
}

\author{
Sri Udayana Tartar ${ }^{{ }^{11,2}, \mathrm{M}_{\text {Mahendradatta }}{ }^{3}, \text { Mursalim }^{3} \text {, Adiansyah }}{ }^{3}$ \\ ${ }^{*}$ Post-Graduate Student, Hasanuddin University, Makassar, South Sulawesi, Indonesia \\ ${ }^{2}$ Department of Fishery Product Processing Technology, Pangkep State Polytechnic of Agricultural, Pangkep, \\ South Sulawesi, Indonesia \\ ${ }^{3}$ Department of Agricultural Engineering and Food Technology, Hasanuddin University Makassar, South \\ Sulawesi, Indonesia
}

\begin{abstract}
Snakehead fish (Channa striata) has fairly high protein content; hence it has the potential to be utilized as a fish protein hydrolyzate. Fish protein hydrolyzate has great benefits in a food sector; therefore in order to obtain functional food products from fish that meet the standards and to utilize snakehead fish head, then enzymatic hydrolyzate products are made using bromelin enzymes. The research was aimed to determine the physicochemical properties of protein hydrolysates of snakehead fish head. It uses a laboratory experimental using a Completely Randomized Design (CRD). The data obtained were analyzed using ANOVA with further testing to determine whether or not the value was influential with Tukey test. The treatment applied was the difference in protein hydrolyzate of snakehead fish head, i.e the weight of head meat of snakehead fish given the treatment of bromelin enzymes with different percentages (6, 8 and 10\%) and with different hydrolysis times (8, 10 and 12 hours). The results of research showed that the best result of treatment were obtained on $10 \%$ bromelin enzyme by temperature hydrolysis of $60^{\circ} \mathrm{C}$ for 8 hours with the criteria of a brownish-yellow protein hydrolyzate, and having a water content of $80.40-77.79 \%$, ash $0.65-0.12 \%$, protein $21.11-18.49 \%$, fat $0.84-$ $0.65 \%$, yield 52.22 - 43.69\%, pH 7.0 - 6.7, brightness $29.93-23.13$.
\end{abstract}

Keywords : Bromelin, Hydrolysis, Protein Hydrolyzate, Snakehead Fish Head

\section{INTRODUCTION}

Fish protein hydrolyzate is a liquid product made from fish by adding proteolytic enzymes to accelerate hydrolysis under controlled conditions with a final product being a mixture of protein components (Pigott and Tucker, 1990). Fish protein hydrolyzate has higher functional properties so that it is more widely used. Today, the development of food industry demands an innovative product of high quality natural ingredients. Protein hydrolyzate as product of enzymatic process is an alternative natural ingredient that can be used for flavor enhancement. One natural ingredient and very potential to be developed is fish with protein contain $15-20 \%$ (Stansby, 1982). Fish that have a high protein content are snakehead (Channa striata), as a native fish to Indonesian waters. The distribution of snakehead fish in Indonesia is almost evenly distributed throughout Indonesia from Sabang to Marauke. In addition, snakehead fish also has many local names such as ikan bocek (Riau), ikan kutuk (Java), haruan 
(Kalimantan), bale salo/bale bolong (Bugis), kanjilo (Makassar), gastor (Sentani, Papua) and others (Asfar et al., 2014).

According to statistical data for snakehead fish in Indonesia from 2000 to 2010 rose by $1.19 \%$. In 2010 the production was 34.017 tons with an increase in production from 2009 by $21.79 \%$ (KKP, 2011). Processing of whole snakehead fish that is developing in Indonesia, includes drying, fumigation, flossing. Snakehead fish floss is a processed product of fishery products that provides output as byproducts. Byproduct produced from fish processing i.e heads, tails, fins, bones and innards by 35\% (Irawan, 2005).

Fisheries by products like fish heads can be utilized as a source of raw materials for making hydrolyzate proteins and can minimize environmental problems. The results of hydrolysis from ingredient extracts that containing protein has the potential to be used as flavoring ingredients. The usefulness of protein hydrolyzate in the food industry was for fortification into food formulations and dietary food supplements, as well as emulsifying ingredients. Several studies in Japan revealed that some processed products that utilize protein hydrolyzate related to their functional properties are good for soups, spices in soy sauce (flavor enhancer), high protein drinks, biscuits, and sauces (Barzana and Gracia, 1994). Nurhayati et al. (2007) studied the protein hydrolyzates of yellow mackerel fish using papain enzyme. A research of protein hydrolyzate has been conducted using raw materials of tilapia (Oreochromis mossambicus) showed that the best fish protein hydrolyzate can be produced with $10 \%$ enzyme concentration with a 4 days incubation period (Ariyani et al, 2003). The production of protein hydrolyzate from yellow mackerel fish (Caranx leptolesis) produces the best fish protein hydrolyzate with $5 \%$ enzyme concentration and 6 hours incubation time and $\mathrm{pH} 7$
(Hidayat, 2005). Pederson (1994) suggested that protein hydrolyzates can be used to improve the characteristics of various food products and also as flavoring.

From results of research concerning protein hydrolyzate, there has been no research on byproduct utilization of snakehead fish head. Thus, the researcher is interested in studying protein hydrolyzates from snakehead fish head. It is expected that this research will provide added value considering that the product can be applied to food sector.

\section{METHODS AND MATERIAL}

\section{A. Research Site}

It was carried out at the Chemical Laboratory of State Agricultural Polytechnic of Pangkep and Plant Assessment Center of Makassar

\section{B. Materials and Tools}

The materials used in this research were: snakehead fish head with a weight of 2 fish per $\mathrm{kg}$ comes from Tempe lake of Wajo district, South Sulawesi, and bromelin enzyme obtained in Delta Malang laboratory, produced by Xian Lyphar Biotech Activity of Enzyme 400.000 u/g min, maltodextrin obtained in Intrako Store of Makassar, and analysis material.

The tools used in the processing procedure are analytic scales (Sartorius TE 64), oven (Memmert), Shellab-branded vacuum oven, Kjeldahl apparatus desiccator, water bath shaker (Wise bath shaker WSB-18), centrifuge (HIMAC CR 21G), and chomameter (Monolta Camera CR-300), cool box, blades, electric meat mill/blender, fermented jars, basins, and bottle package and tools for analysis. 


\section{Sample Preparation}

Procedure for making protein hydrolyzate of snakehead fish head (Modified by Nurhayati et al. 2007) as follows: snakehead fish is weeded by removing the gills, and washed. After weeding, the head of snakehead fish is separated to be used as raw material for hydrolyzate.

\section{Metode}

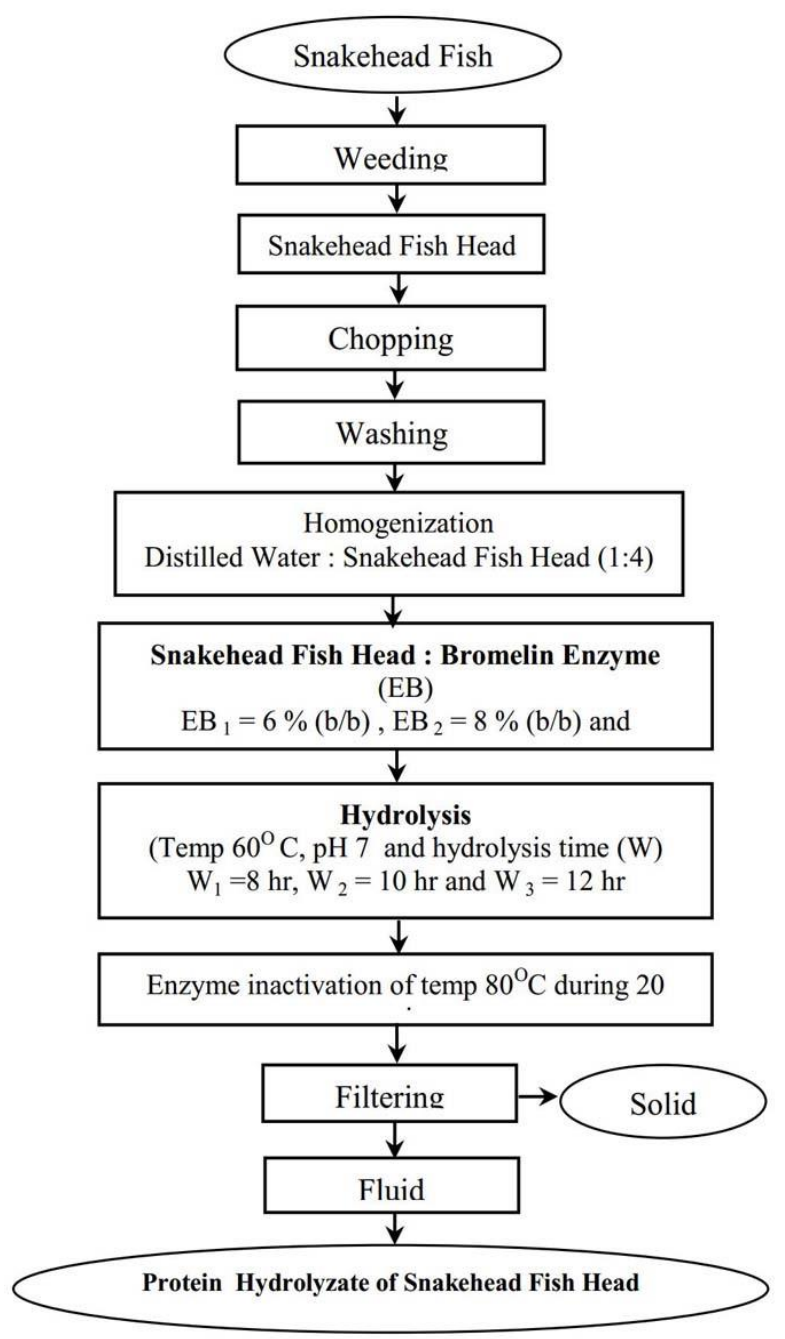

Figure 1. Flowchart of making protein hydrolysate of snakehead fish head (Modified by Nurhayati et al. 2007)

The making of protein hydrolyzates of snakehead fish head is done through enzymatic reactions using bromelin enzyme. In this research, a method of making protein hydrolyzate follows a method of Nurhayati et al. (2007) as modified. The working procedure of research is to reduce the size of fish head using a stuffer machine. Then, bromelin enzyme was weighed according to treatment, the treatment of protein hydrolyzate was $100 \%$ snakehead fish head by adding bromelin enzyme $\mathrm{EB}_{1}$ $\left.=6 \%(\mathrm{~b} / \mathrm{v}), \mathrm{EB}_{2}=8 \%(\mathrm{~b} / \mathrm{v}), \mathrm{EB}_{3}=10 \%(\mathrm{~b} / \mathrm{v})\right)$ and hydrolyzed with $\mathrm{pH} 7$ using a temperature of $60^{\circ} \mathrm{C}$ and hydrolysis time (W) with a treatment of $\mathrm{H}_{1}=6$ hours, $\mathrm{H}_{2}=10$ hours and $\mathrm{H}_{3}=12$ hours. The results of protein hydrolyzate of snakehead fish head were inactivated its enzymes with cooking temperature of $80^{\circ} \mathrm{C}$ for 20 minutes. The protein hydrolyzate of inactivated snakehead fish head is separated by solids and liquids by using filter paper to separate the filtrate to obtain liquid.

It uses an experimental study with a completely randomized design. The results of protein hydrolyzate for snakehead fish head were analyzed proximate and brightness.

\section{Water Content with Oven Method (AOAC 2005)}

Determination of water content is based on differences in material weight before and after drying. Initially, the empty cup was dried in oven for 30 minutes at a temperature of $105^{\circ} \mathrm{C}$ and then cooled in an exicator for 15 minutes, then weighed 3 - 5 grams of protein hydrolyzate of snakehead fish head and put in a cup then dried in an oven $105^{\circ} \mathrm{C}$ for 6 hours. The cup was cooled in an exicator for 30 minutes and then weighed. Water content is calculated by using a formula:

$$
\text { Water Content }(\%)=\frac{B-C}{B-A} \times 100 \%
$$




\section{Protein Content (AOAC, 2005)}

Protein solution is taken $10 \mathrm{ml}$ and dilute it to $100 \mathrm{ml}$ with distilled water in a flask, then put into Kjeldahl flask $500 \mathrm{ml}$ and $10 \mathrm{ml} \mathrm{H}_{2} \mathrm{SO}_{4}(93 \%-98 \%$ free-N) add 5 grams of mixture $\mathrm{H}_{2} \mathrm{BO}_{3}, \mathrm{Na}_{2} \mathrm{SO}_{4}-\mathrm{HgO}$ for catalyst. Rub thoroughly and continue for 30 minutes. After cooling, wash it in Kjeldahl flask with distilled water then boil again for 30 minutes.

After cooling, adding $140 \mathrm{ml}$ of distilled water, and $35 \mathrm{ml}$ of $\mathrm{NaOH}-\mathrm{Na}_{2} \mathrm{~S}_{2} \mathrm{O}_{3}$ and a few grains of zinc. Then distilled, $100 \mathrm{ml}$ of distillate was stored in Erlenmeyer containing $25 \mathrm{ml}$ of saturated solution of boric acid and a few drops of PP indicator. The solution is obtained with $0.02 \mathrm{NHCl}$.

\section{Ash Content with Gravimetric Method (AOAC, 2005)}

As many as 3-5 gr samples is weighed and put in a cup, then burned until there is no smoke. After being put into the furnace, it is burned to gray. Ash is done in two stages, first at $400^{\circ} \mathrm{C}$ and second at $550^{\circ} \mathrm{C}$. After the weight of cup is constant, the cup is then cooled in a desiccator and weighed. The ash content is determined by using a formula:

$$
\text { Ash Content }(\%)=\frac{A}{B} x 100 \%
$$

\section{Fat Content (AOAC, 2005)}

A sample of 2 grams is put in filter paper and in the sleeve. The fat flask that has been weighed then connected with the fat sleeve. Samples and fat solvents (diethyl ether) are put into fat sleeve. The series of fat flask and sleeves are mounted on the Soxhlet extractor which is connected to a recirculation chiller $4^{\circ} \mathrm{C}$. Fat samples were extracted at $60^{\circ} \mathrm{C}$ for $7-8$ hours. The mixture of fat and solvents contained in fat flask is distilled until drying.
Fat flask is put in the oven at $105^{\circ} \mathrm{C}$ for 2 hours. The flask is cooled in a desiccator until the weight is constant. Fat content is calculated by using a formula:

$$
\text { Fat Content }(\%)=\frac{W 3-W 1}{W 2} \times 100 \%
$$

\section{Color (Hutching JB. 1999)}

Color measurement was made using a colorimeter. The color reading included lightness (L), redness (a) and yellowness (b). The equipment was standardized with a white color standard.

\section{E. Data Analysis}

The experimental design used in this research was a completely randomized design to analyze the effect of bromelin enzyme concentration and hydrolysis time on the quality of the protein hydrolyzate for snakehead fish head. Data analysis using ANOVA to see the effect of differences in concentration and continued with Tukey test to see differences in each treatment.

\section{RESULTS AND DISCUSSION}

Table 1. Proximate composition of protein hydrolyzates of snakehead fish head

\begin{tabular}{|c|l|c|}
\hline No & \multicolumn{1}{|c|}{ Component } & Composition (\%) \\
\hline 1 & Water Content & $80.40-77.79$ \\
\hline 2 & Ash Content & $0.65-0.12$ \\
\hline 3 & Protein Content & $21.11-18.49$ \\
\hline 4 & Fat Content & $0.84-0.65$ \\
\hline
\end{tabular}


Water Content of Protein Hydrolyzate of Snakehead Fish Head

Water content of food ingredients also determines acceptability, freshness, and durability of food ingredients. Water content of food affects the durability of food to microbial attacks which are expressed by $a_{w}$, i.e amount of free water that can be used by microorganisms for growth (Winarno, 1989). The average of protein hydrolyzate of snakehead fish head is $78.87 \%$. The highest water content was obtained from the addition of $10 \%$ bromelin enzyme which was hydrolyzed by 10 hours which was equal to $80.40 \%$ while the lowest value in the treatment of bromelin enzyme addition was $10 \%$ and the hydrolysis time for 8 hours was $77.79 \%$.

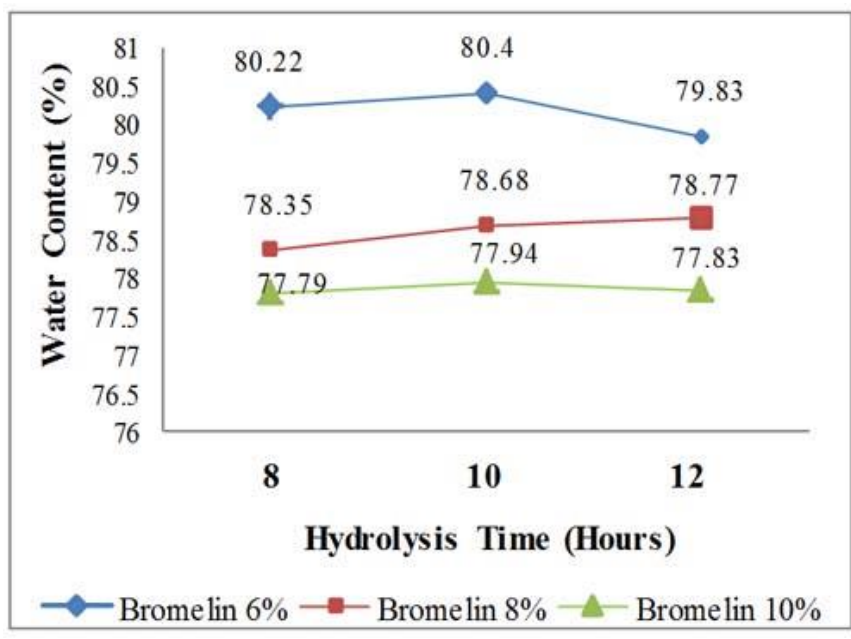

Figure 2. Relation of Bromelin enzymes and hydrolysis time against water content of protein hydrolyzate for snakehead fish head

A relation of bromelin enzyme and hydrolysis time to water content of protein hydrolyzate for snakehead fish head as showed on Figure 2 wherein the water content of protein hydrolyzate for snakehead fish head tend to decrease by increasing the enzyme, it caused by the treatment of bromelin enzyme performance so that occur fragmentation during hydrolysis. According to Savitri (2011) a decrease in water content during hydrolysis is caused by a change in protein that produces a number of moisture, fragmentation of amino acids as well as from the diffusion of water vapor in a closed container so that a water vapor balance occurs in the system.

\section{Ash Content of Protein Hydrolysate for Snakehead} Fish Head

Ash content is one component in food ingredients. This component consists of minerals such as potassium, phosphorus, sodium, magnesium, calcium, iron, manganese, and copper (Winarno, 1995). Largely of food consists of $96 \%$ organic matter and its water covering mineral elements. The combustion process of food ingredients to a temperature of $600^{\circ} \mathrm{C}$ will cause organic matter to burn, but inorganic materials do not burn, namely in the form of ash consisting of various mineral elements such as $\mathrm{Ca}, \mathrm{Mg}$, $\mathrm{Na}, \mathrm{P}, \mathrm{K}, \mathrm{Fe}, \mathrm{Mn}$ and $\mathrm{Cu}$.

The average value of ash content of protein hydrolyzate for snakehead fish head is $0.38 \%$. The highest ash content was obtained from the addition of $6 \%$ bromelin enzyme which was hydrolyzed during 8 hours by $0.65 \%$ while the lowest ash content was obtained from the addition of $10 \%$ bromelin enzyme which was hydrolyzed during 12 hours by $0.12 \%$. A relation of bromelin enzyme and hydrolysis time to water content of protein hydrolyzate for snakehead fish head as showed on Figure 3. The low of ash content of hydrolyzate protein for snakehead fish head is caused by the ability of bromelin enzyme to hydrolyze ash content of snakehead fish head, therefore the longer hydrolysis time the lower of ash content of protein hydrolyzate for snakehead fish head. Irma, et al (1997) 
stated that minerals are inorganic substances that undergo changes due to enzyme activity. The low ash content obtained is due to wasting some minerals which are insoluble in the hydrolysis stage. According to Budiyanto and Yulianingsih (2007) ash is a residue or residual combustion of organic matter in the form of inorganic materials.

According to Amiza et.al (2013) stated that ash content of protein hydrolyzate for snakehead fish head is lower than catfish (3.35 - 4.45\%). Salamah et al. (2011) stated that high ash content in HPI is caused by the addition of alkali compounds such as $\mathrm{NaOH}$ and/or acid compounds such as $\mathrm{HCl}$, in the process of protein hydrolysis aimed at achieving optimum $\mathrm{pH}$ value of the enzyme and keeping $\mathrm{pH}$ remain constant during hydrolysis process so that the enzyme peptide breaks can continue.

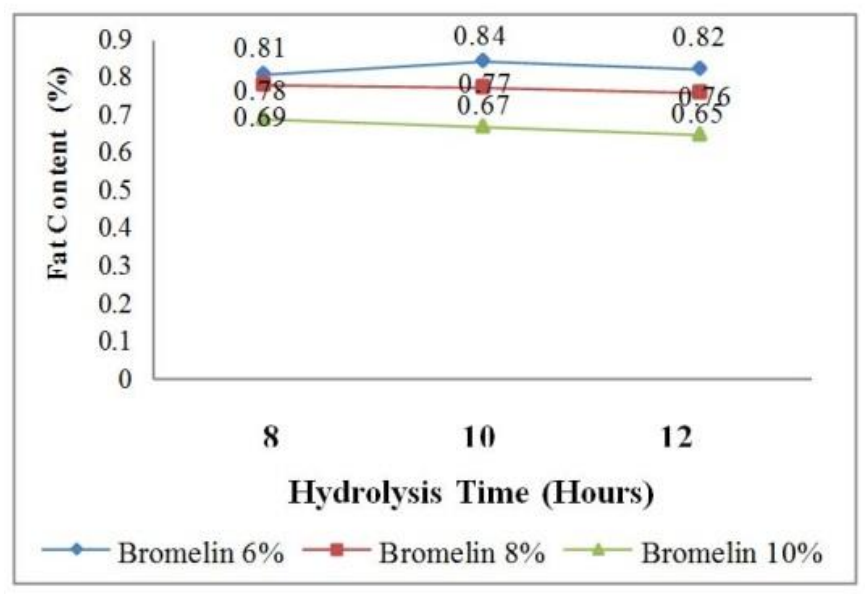

Figure 3. Relation of Bromelin enzymes and hydrolysis time against ash content of protein hydrolyzate for snakehead fish head

\section{Protein Content of Protein Hydrolyzate for Snakehead Fish Head}

Protein is a source of amino acids consisting of elements $\mathrm{C}, \mathrm{H}, \mathrm{O}$, and $\mathrm{N}$. it serves as a builder of new tissues, regulates metabolic processes in the body and as fuel when the energy needs are not met by fat and carbohydrates (Winarno, 1980) The average value of protein content of protein hydrolyzates for snakehead fish head is $19.75 \%$. The highest protein content was obtained from the addition of $10 \%$ bromelin enzyme which was hydrolyzed at 8 hours by $21.11 \%$ while the lowest protein content was obtained from the addition of $6 \%$ bromelin enzyme which was hydrolyzed at 8 hours by $18.81 \%$. The result of protein content of protein hydrolyzate for snakehead fish head can be seen in Figure 4 that the more addition of bromelin enzymes the higher of protein content produced and the longer of hydrolysis time used, it also shows the tendency of protein content to increase.

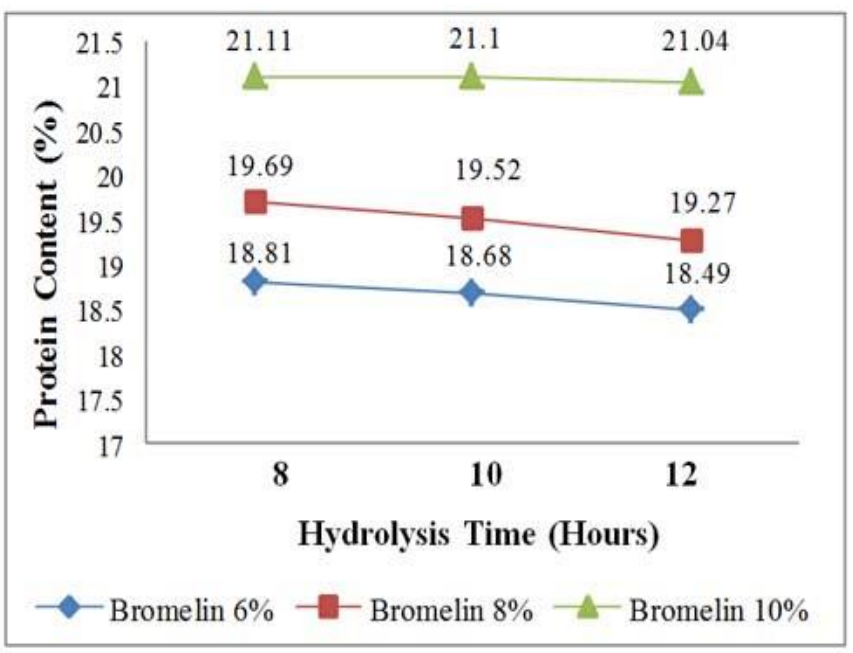

Figure 4. Relation of Bromelin enzymes and hydrolysis time against water content of protein hydrolizate for snakehead fish head

According to Prasetyo et al (2012) stated that the addition of bromelin enzymes that are hydrolase results in an increase in protein content as result from the hydrolysis process of bromelin enzyme which will hydrolyze more fish tissue and cause the structure of meat to be more tenuous and easily hydrolyzed dissolved proteins. Bromelin enzyme is a 
protease enzyme that can break down protein in collagen and muscle fibers. Proteolysis of collagen and muscle fibers can cause shear force of collagen and muscle fiber decrease, so that the density of meat decreases (Lee at. al., 1994 in Prasetyo et al, 2012). Proteinolysis of myofibril produces protein fragments with shorter peptide chains, the more proteolysis in myofibrils, the greater dissolved protein. The more concentration of bromelin enzyme added, the rate of hydrolysis will increase.

\section{Fat Content of Protein Hydrolizate for Snakehead Fish Head}

The average value of fat content of protein hydrolyzates for snakehead fish head is $0.75 \%$. The highest fat content was obtained from the addition of $6 \%$ bromelin enzyme which was hydrolyzed at 10 hours by $0.84 \%$ while the lowest protein content was obtained from the addition of $10 \%$ bromelin enzyme which was hydrolyzed at 12 hours by $0.65 \%$. Protein hydrolyzates of snakehead fish head meet the requirements for hydrolyzates type $\mathrm{A}$ because they have a fat content of less than $0.75 \%$ (FAO, 2011). Protein hydrolyzate that have low fat content are generally more stable against fatty oxidation reactions than fish protein hydrolyzates which have high fat content (Nilsang et al. 2005).

The results of fat content of protein hydrolyzate for snakehead fish head can be seen in Figure 5. It can be seen that the more addition of bromelin enzymes the lower of fat content produced and the longer of hydrolysis time used, it shows the tendency of fat levels to decrease, this is due to hydrolysis, this membranes tends to gather and form insoluble bubbles, resulting in the loss of membrane lipids and can impact to the decrease fat content. Winarno (1980) states that fat can be broken down by microbes or certain enzymes to produce fatty acids.
The use of bromelin enzymes can break down fat into more fatty acids along with the longer of hydrolysis time.

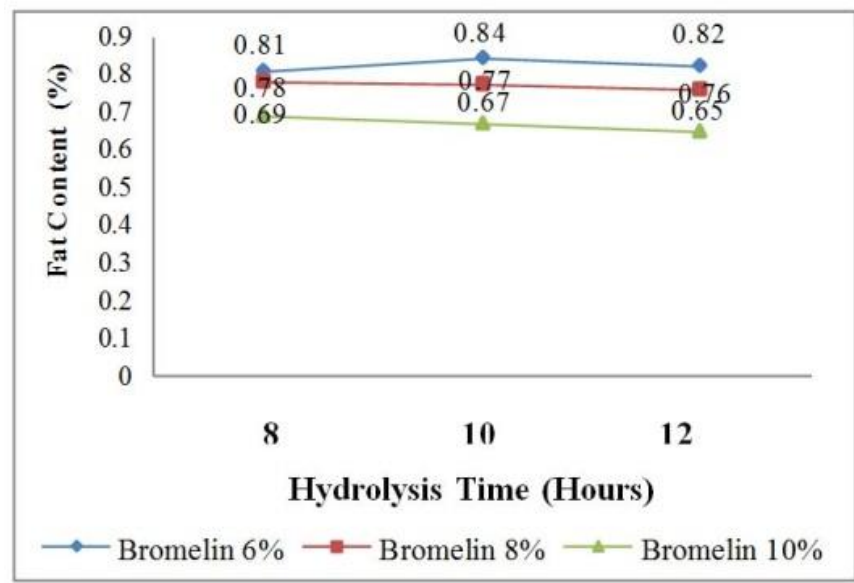

Figure 5. Relation of Bromelin enzymes and hydrolysis time against fat content of protein hydrolizate for snakehead fish head

Shahidi et al. (1995) explained that during the enzymatic hydrolysis process changes in fish tissue structure are very fast, causing fat levels to decrease. Bromelin enzymes can break down protein bonds in snakehead fish head, by protein hydrolysis the lipoprotein bond will be broken, hence the binding fat by the bond will come out and gather into one (Winarni, 2007).

\section{Color (Hutching, 1999)}

Color characterization of protein hydrolyzates for snakehead fish head is conducted by using Hunter notation system, where brightness (L) has a value between 0 (black) and 100 (white), red-green (a) has a value between 80 red and - 80 (green), blue-yellow (b) has a value between 70 (yellow) and -70 (blue). 
Table 2. Level of brightness of protein hydrolyzate for snakehead fish head

\begin{tabular}{|c|c|}
\hline $\mathrm{HPl}$ & $\mathrm{L}$ \\
\hline $\mathrm{EB}_{1} \mathrm{H}_{1}$ & 23.13 \\
\hline $\mathrm{EB}_{1} \mathrm{H}_{2}$ & 23.20 \\
\hline $\mathrm{EB}_{1} \mathrm{H}_{3}$ & 25.50 \\
\hline $\mathrm{EB}_{2} \mathrm{H}_{1}$ & 29.47 \\
\hline $\mathrm{EB}_{2} \mathrm{H}_{2}$ & 26.90 \\
\hline $\mathrm{EB}_{2} \mathrm{H}_{3}$ & 29.00 \\
\hline $\mathrm{EB}_{3} \mathrm{H}_{1}$ & 29.97 \\
\hline $\mathrm{EB}_{3} \mathrm{H}_{2}$ & 29.93 \\
\hline $\mathrm{EB}_{3} \mathrm{H}_{3}$ & 30.87 \\
\hline
\end{tabular}

Protein hydrolyzate of snakehead fish head shows a combination of red and yellow with a brightness value $(\mathrm{L})$ of 30.87 . L-value has a scale from 0 to 100 ; the greater of $\mathrm{L}$, the more bright the sample. The color $\mathrm{L}$ is a coordinate of bright level $(\mathrm{L}=0$ black and $\mathrm{L}=100$ white), the color $\mathrm{L}$ correlates with Mallard product with a correlation value of $(-0.205)$. As results of observation for $\mathrm{L}$ color indicate that Mallard product increase then the level of $\mathrm{L}$ color is dark. The result of assessment shows that longer of hydrolysis time the higher of L-value or brightness level where the highest $\mathrm{L}$-value is the treatment of the addition of $10 \%$ enzyme and 12 hours hydrolysis time.

\section{CONCLUSION}

The best protein hydrolyzate of snakehead fish head was obtained in the treatment of $10 \%$ bromelin enzyme by temperature hydrolysis $60^{\circ} \mathrm{C}$ during 8 hours with a brownish-yellow protein hydrolyzate protein criteria, brightness L 29.93 and water $78.87 \%$, protein $21.11 \%$, fat $0.65 \%$ fat contents.

\section{ACKNOWLEDGMENT}

This research was funded by the Directorate of Higher Education, Research and Technology through a research grant program in 2019.

\section{REFERENCES}

[1]. Ariyani, F. M., Saleh, Tazwir dan Nurul H. 2003. ptimization of the Production Process of Fish Protein Hydrolyzate (HPI) from Mujair (Oreochromis mossambicus). Indonesian Fisheries Research Journal Vol 9 Nomor 5

[2]. Amiza MA, Ow YW, Faazaz AL. 2013. Physicochemical properties of silvercatfi sh (Pangasius sp.) frame hydrolysate. International Food Research Journal 20(3): 1255-1262.

[3]. Asfar, M., Tawali, A.B., Abdullah, N., Mahendradatta,M. 2014. Extraction of Albumin of Snakehead Fish (Channa striatus) In Producing The Fish Protein Consentrate (FPC). IJSTR Vol. 3.

[4]. AOAC (Association of Official Analytical Chemyst) (2005). Official Method of Analysis of The Association of Official Analytical of Chemist. Arlington (USA): The Association of Official Analytical Chemist, Inc.

[5]. Barzana E, Gracia GN. 1994. Production of fi sh protein consentrate. Martin, A.M.(ed) Fisheries Processing Biotechnology Application. London (UK): Chapman \& Hall (207-222).

[6]. Budyanto, A dan Yulianingsih. 2007. Effect of Temperature and Time of Extraction on Rectin Character from Siam Citrus Dregs (Citrus nobilis L). Bogor Agricultural Institute. Bogor

[7]. [FAO] Food and Agricultural Organization.2011. Fish protein concentrate. http://www.fao.org/ [4 Juli 2013]. 
[8]. Hidayat, N., M.C. Padaga, dan S. Suhartini, 2005, Industrial Microbiology . Penerbit ANDI, Yogyakarta

[9]. Hutching JB. 1999. Food Color and Appearance. Chapman and Hall Food Science Book. Gaithersburg Maryland (USA): Aspen Publishers Inc.

[10]. Irawan, A. 2005. Preservation of Fishery Products.CV. Aneka, Solo Irma K., Dede Z., Arief., Ela TS. 1997. Effect of Papaya Gum Concentration (Caricapapaya, Linn) and Hydrolysis Time on Hydrolyzate of Shrimp Head Protein (Karapaks penaeus monodon).FTI-UNPAS

[11]. Nurhayati T, Salamah E, Hidayat T. 2007. The characteristics of selar (Caranx leptolepis) protein hydrolyzate are enzymatically processed. Fisheries Product Technology Bulletin 10(1): 23-34.

[12]. Nilsang S, Lertsiri S, Suphantharika M, Assavanig A. 2005. Optimization of enzymatic hydrolysis of fi sh soluble concentrate by commercial protease. Journal of Food Engineering 70(1): 571-578

[13]. Pigot GM, BW Tucker. 1990. Utility Fish Flesh Eff ectively While Maintaining Nutritional Qualities. Seafood Eff ect of Technology on Nutrition. New York (AS): Marcel Dekker.

[14]. Prasetyo, M.N., Sari, N., Budiyati, C.S., 2012. Making Ketchup from Cork Fish by Enzymatic Hydrolysis Using Pineapple Juice. Journal of Chemical and Industrial Technology

[15]. Pedersen. 1994. Removing bitternes from protein hidrolysats. Di dalam: Food Industri X. Chicago: Institute of Food Technologists USA.

[16]. Salamah E, Nurhayati T, Widadi IR. 2011. Making and characterizing protein hydrolyzates from African catfish (Clariasgariepinus) using the enzyme papain. Journal of Processing Fisheries Products
[17]. Stansby ME. 1982. Properties of fish oils and their application to handling of fish and to nutritional and industrial use. Di dalam: Martin RE (ed.). Chemistry and Biochemistry of Marine Food Products. Westport Conecticut : The AVI Publishing Company.

[18]. Savitri, D.R. 2011. Application of Enzymatic Hydrolysis and Fermentation Process in Processing Kupang White Condiment (Corbula Faba H). Essay. Department of Aquatic Product Technology, Faculty of Fisheries and Marine Sciences. IPB

[19]. Shahidi F, Han XQ Synowiecki J. 1995. Production and characteristics of proteinhydrolysates from capelin (Mallotusvillosus). Food Chemistry 53(3): 285293.

[20]. [KKP]. Ministry of Maritime Affairs and Fisheries. Statistics of aquaculture . http://statisti.kkp.go.id [13 April 2013].

[21]. Winarno, 1995. Food Enzymes. Jakarta: PT.Gramedia Main Library

[22]. Winarno, F. G., Fardiaz, S., and Fardiaz, D. 1980. Introduction to Food Technology. Gramedia, Jakarta

[23]. Winarni. S. 2007. Enzymatic VCO (Virgin Coconut Oil) Making Process Using Rough Papain. Journal of Food Technology. 8: 136-141

\section{Cite this article as :}

Sri Udayana Tartar, M Mahendradatta, Mursalim, Adiansyah, "Characteristic of Protein Hydrolyzate of Snakehead Fish (Channa striata) Head by Using the Treatment of Different Bromelin Enzyme Concentration and Hydrolysis Time", International Journal of Scientific Research in Science and Technology (IJSRST), Online ISSN : 2395-602X, Print ISSN : 2395-6011, Volume 6 Issue 4, pp. 188-196, July-August 2019. Available at doi : https://doi.org/10.32628/IJSRST196439 Journal URL : http://ijsrst.com/IJSRST196439 